\title{
What caused the Viking Age?
}

\author{
James H. Barrett*
}

This paper addresses the cause of the Viking episode in the approved Viking manner - headon, reviewing and dismissing technical, environmental, demographic, economic, political and ideological prime movers. The author develops the theory that a bulge of young males in Scandinavia set out to get treasure to underpin their chances of marriage and a separate domicile.

Keywords: Scandinavia, Britain, Ireland, North Sea, Viking Age, early medieval, Abbasid, treasure, silver

\section{Introduction}

The Scandinavian diaspora of the late eighth to mid-eleventh centuries AD known as the Viking Age was both widespread in scale and profound in impact. Long-range maritime expeditions facilitated a florescence of piracy, trade, migration, conquest and exploration across much of Europe - ultimately extending to western Asia and the eastern seaboard of northern North America (Brink \& Price in press). This diaspora contributed to state formation and/or urbanism in what are now Ireland, Scotland, England, Russia and the Ukraine - not to mention within Scandinavia itself. It was one of the catalysts leading to fragmentation of the Carolingian empire and it created the semi-independent principality of Normandy.

As one of the last 'barbarian migrations' of post-Roman Europe, it is also among the best documented. Its study is thus uniquely important for an understanding of European history. It also provides good examples of three processes of relevance to the archaeology of the wider world: the potential impact of small-scale but highly militarised non-state communities on neighbouring 'complex societies', the development of transnational identities in a precapitalist world and the seaborne colonisation of islands. Studying the causes of the Viking Age is potentially as illuminating and complex as interpreting the decline of the Roman Empire.

Many discussions of the causes of the Viking Age have been conducted in contexts that are regional (e.g. Näsman 2000a; Vésteinsson et al. 2006). Others address the problem within broad narratives (e.g. Roesdahl 1991: 187-94; Richards 2000: 18-19; Byock 2001: 82-4; Sawyer 2003a: 106-9; Hadley 2006: 16-21; Woolf 2007: 52-7). Yet others challenge the relevance of the Viking Age as a socio-economic watershed or a useful unit of analysis (e.g. Svanberg 2003: 201-3; Hodges 2006).

The hesitancy in some quarters to view the 'Viking' diaspora as meaningful may ultimately owe its roots to a reaction against the gross misuse of Viking Age archaeology as racist

* McDonald Institute for Archaeological Research, University of Cambridge, Downing Street, Cambridge, CB2 3ER, UK (Email: jhb41@cam.ac.uk)

Received: 21 November 2007; Revised: 11 April 2008; Accepted: 14 May 2008

ANTIQUiTy 82 (2008): 671-685 
propaganda by the National Socialists and others between 1920 and 1945 (see Müller-Wille 1994; Nondier 2002: 509-11). Nevertheless, there is a problem to resolve, and to understand the early Middle Ages in Europe one must consider developments both within and between regions (cf. McCormick 2001; Wickham 2005). Näsman (2000a) and Svanberg (2003) demonstrate that Scandinavian material culture was highly regionalised in the period under consideration.

Despite these practical and historical impediments, a small number of studies have sought to grapple with the causes of the Viking Age in holistic fashion, limiting the danger of information overload through varying combinations of generalisation and case study (e.g. Sawyer 1982a; Lund 1989; Myhre 1993; Hernæs 1997; Randsborg 2000; McCormick 2001; Simek 2004). Adopting this tradition, what follows combines an overview with more detailed consideration of early Viking Age (particularly late eighth- to early ninth-century) Scandinavian raiding in the west. It starts from the premise that cause must precede effect in time. This may be obvious, but the disproportionate abundance of evidence from the middle of the ninth century and later has often led scholars of the Viking Age to read history backwards, from the known to the unknown, potentially skewing our understanding of causal chains.

Collectively, previous scholarship has considered the causes of the Viking Age in terms of one or more of the following:

- Technological determinism;

- Environmental determinism;

- Demographic determinism;

- Economic determinism (the growth of urbanism and trade);

- Political determinism (the weakness of neighbouring empires and/or the centralisation of power within Scandinavia);

- Ideological determinism.

Each explanation combines these factors in differing configurations, creating a wide variety of possible models. It would be impractical to review the resulting historiography in a work of this length. Instead, this paper will return to first principles, the ingredients of the story of the Viking Age, briefly considering them in light of both present knowledge within 'Viking studies' (including archaeology, history and related fields) and insights from the social sciences (specifically anthropology and sociology). In so doing it seeks to present a brief overview of existing wisdom, to challenge several problematic assumptions, to introduce a few new issues which have not yet received the attention they merit and to propose a new explanation.

\section{Technological determinism}

Among the traditional 'causes' of the Viking Age, the demotion of naval technology and seafaring knowledge is perhaps the most surprising to the non-specialist. The high level of technological skill and social signalling embodied by boats and ships in Viking Age 
Scandinavia has been reinforced by all research since the first great ship-burial excavations of the nineteenth and early twentieth centuries (e.g. Crumlin-Pedersen 1995; Owen \& Dalland 1999; Westerdahl 2008). However, it is equally clear that large-scale seaborne raiding, conquest and/or migration could have emanated from Scandinavia long before, thus reducing the causative power of Viking ships.

Weapon sacrifices, at Nydam I (fourth century AD) in Denmark for example, indicate the long-range movement of large armies by boat during the Roman Iron Age (Randsborg 1995). In the fifth century, ships of northern Germanic origin facilitated a scale of AngloSaxon influence on (and, based on DNA evidence, migration to) Britain that exceeded or equalled that of their Viking Age successors (cf. Hills 2003; Oppenheimer 2007). Thus the question of ship technology, particularly developments of keel and sail, are not pivotal (Haywood 1999). It is now thought that sails may have been adopted in Scandinavia several centuries before the Viking Age in any case (Crumlin-Pedersen 2007).

If something meaningful did change in the late eighth century it is likely to be in how existing technology was employed, be it changes in tacking practices (Carver 1995) or a shift to 24-hour sailing (cf. McCormick 2001: 788). In this hypothetical eventuality, we could best interpret change as reflecting the motivation to travel further and quicker - and thus as an effect of the Viking Age. In brief, ships capable of carrying warriors long distances are a necessary pre-requisite for the Viking Age, but clearly they did not 'cause' it.

\section{Environmental determinism}

A second old chestnut of limited relevance is climate, specifically the possible impact of the Medieval Warm Period (MWP) (e.g. Dansgaard et al. 1975; Dugmore et al. 2007: 14). The problems here are the timing of the MWP itself and of putative climate-induced settlement expansion. Some climatological research is consistent with warming in the centuries leading up to the end of the first millennium AD (e.g. Dahl-Jensen et al. 1998). Conversely, other studies would place the MWP after the turn of the millennium and emphasise its regional variability (e.g. Bradley et al. 2003). It has even been argued that the MWP never existed (e.g. Hughes \& Diaz 1994). Thus favourable climatic conditions may or may not have enhanced opportunities for Scandinavian settlement in Iceland (and later Greenland). Even if they did, the earliest evidence of Norse settlement in Iceland presently dates to the $870 \mathrm{~s}$ (Vésteinsson et al. 2006). This is almost a century after the first certain raids of the early Viking Age (such as the infamous attack on Lindisfarne in 793). Greenland in turn was not settled by Scandinavian migrants until the end of the tenth century (Arneborg 2003), with brief forays to the new world following shortly thereafter (Wallace 2003).

\section{Demographic determinism}

In more general terms, Scandinavia did share in the widespread European population and settlement boom of the end of the first millennium AD - a well-established phenomenon which may partly reflect environmental conditions (e.g. Fossier 1999; Dyer 2002). Thus the issue of climate merges into that of demography. But in its most simplistic form, that of nebulous 'population pressure', this too can be dismissed as a realistic cause of the Viking Age (Hernæs 1997: 57-8). The chronology of settlement expansion varies by the region in 
Scandinavia - with some locations showing little change from the Roman Iron Age until economic crisis and plague in the fourteenth century (e.g. Skre 2001). Nevertheless, in many areas forest clearance and settlement expansion is now known to have progressed during the course of the Viking Age, rather than preceding it (e.g. Andersen et al. 1988; Karlsson \& Robertsson 1997; Näsman 2000a: 2-3). In parts of Norway, for example, it may well be characteristic of the end of the period (Myhre 1998).

Related to the issue of demography is a more implicit, but widely held, assumption that Viking Age settlement expansion entailed a mechanistic 'wave of advance' in which the Germanic-speaking peoples of Scandinavia slowly colonised neighbouring territories. The western diaspora can provide one example (Barrett 2006; cf. Woolf 2007: 52-7, 286-9). It is commonly treated as a sequential process beginning with the Northern Isles of Scotland, from which it is presumed Scandinavians first operated as raiders in mainland Britain, Ireland and sometimes even continental Europe (e.g. Sawyer 2003a: 109; Ridel 2007). After that came conquest and settlement, spreading to Ireland and ultimately - under the dynasty of Ímar/Ivar of Dublin and his cronies - to Anglo-Saxon England (see Wormald 1982: 141; Biddle \& Kjølbye-Biddle 2001: 81-4). The extreme version of this wave of advance model envisions the foundation of an early (or even pre-) Viking Age Scandinavian kingdom in Scotland, Laithlinn, which moved its base of operations to Dublin in the 840s (O Corráin 1998a; Sawyer 2003b; Stefánsson 2003: 204; cf. Etchingham 2007). Although the second (Irish and English) chapter of this story is likely to be correct (Downham 2007), the assumption of early Scandinavian settlement in Atlantic Scotland cannot yet be supported on the basis of reliable evidence.

The 'wave of advance' model is ultimately traceable to post-Viking Age Icelandic and Norwegian sources in which early pirate settlements in the Northern Isles were assumed to have existed (e.g. Guðmundsson 1965: 7-8; Ekrem \& Mortensen 2003: 67). However, there is no evidence from settlement sites, graves, hoards or the documentary record to suggest that Scandinavian migrants were living in Atlantic Scotland prior to the mid-ninth century (Barrett 2003 and references therein). Newly published 'early' radiocarbon dates from Viking Age settlements in the Northern Isles (Hunter 2007: 139-40; Ballin Smith 2007: 289-94) do not change this conclusion. None unambiguously pre-date the midninth century. Marine reservoir effects from cooked fish, not to mention statistical chance, could easily account for the one anomalously early date from Norwick, Shetland. It was on carbonised food deposits adhering to a soapstone pot (Ballin Smith 2007: 289, 293; cf. Barrett \& Richards 2004). Similarly, a single pre-ninth-century date from phase 7.1 at Pool, 'may represent earlier residual material from a levelling surface' (Hunter 2007: 139).

Weber's (1992; 1993; see also Ballin Smith 1995) suggestion that pre-Viking Age combs from Orkney were manufactured using reindeer antler imported from Scandinavia has also now been re-evaluated (Ashby 2006). Several Orcadian combs of Pictish style were indeed probably manufactured using this raw material, but none of these can be demonstrated to pre-date the ninth century based on stratigraphy or absolute dating. In sum, there is no reason to think that Norse settlement in the Scottish isles was prior to the first documented over-wintering of Viking armies in Ireland (AD 841), England (850/1) and Frankia (852/3).

After this date, there is clear evidence for the transfer of information and objects around the Irish Sea (e.g. Graham-Campbell 1998; Johnson 2001; Paterson 2001). In the few 
cases where the chronology of this exchange can be established, however, Ireland often had precedence. One example is the presence of belt buckles of probable Irish manufacture in Scottish Viking Age graves (Paterson 2001). Another is the use of fairly standardised arm bands as a medium for storing silver bullion. These circulated widely in late ninth- and early tenth-century Ireland (Sheehan 1998: 178), only being adopted (in the altered style known as 'ring-money') in Atlantic Scotland in the mid-tenth century (Warner 1976; GrahamCampbell 1995: 38-40). In cases where geographically 'Scottish' styles from Dal Riata or Pictland may have influenced Irish fashion, such as the adoption of bossed penannular brooches in the late ninth century, the chronology post-dates Scandinavian settlement in both regions (Graham-Campbell 1975; Michelli 1993; Johnson 2001).

Lastly, there is now a limited quantity of evidence for human migration patterns from isotopic analysis of teeth from Viking Age burials in Atlantic Scotland. It too may imply the redistribution of population around the 'Insular' world, rather than direct immigration from Scandinavia (Montgomery et al. 2003; Montgomery \& Evans 2006).

Starting from this archaeological source material (rather than the assumptions of much later medieval texts), it may be prudent to reconstruct a scenario consistent with how migration has been observed to unfold cross-culturally. Rather than spreading gradually from a source population, migrants move along networks (e.g. Brettell 2000: 107). The nodes of these networks are places which have either what migrants seek (e.g. perceived economic opportunities) or information and support (often from related prior migrants) to help them find it. Thus distances are conceptualised in terms of social space rather than physical geography (cf. Näsman 1991) - potentially leading to 'leap-frog' patterns of mobility. This phenomenon is observed in an increasingly transnational twentieth- to twentyfirstcentury world (e.g. Santiago-Irizarry 2008), and its potential relevance to prehistoric societies is corroborated by archaeological examples from as far afield as the Mediterranean (Forenbaher \& Miracle 2005) and the Caribbean (Keegan 2004).

In the earliest decades of the Viking Age the objective of short-term Scandinavian migrants was portable wealth, which was probably more abundant in Ireland's ubiquitous monasteries (including Iona in Irish speaking Dal Riata, Argyll) and in mainland Pictland than in the less densely settled islands of northern Scotland. This is not to say that there was no treasure in the north (cf. St Ninian's Isle, Shetland, Small et al. 1973) - but the relative difference must have been substantial. Only later, in the period of settlement, would the Northern Isles have been equally relevant destinations for seafaring Scandinavians. The recent suggestion that early medieval Ireland was impoverished (Wickham 2005: 817) is not really relevant here, partly because this judgement is not vis-à-vis Atlantic Scotland and partly because the case is overstated. It relies largely on a comparison with Denmark which omits differences in cultural practices surrounding the deposition of elite metalwork in each region. Unlike Denmark, metalwork was first routinely consigned to water or earth in Ireland after the Viking Age had started - at which point the island was demonstrably wealthy (cf. Hedeager 1992: 70-81; Sheehan 1998).

In support of the 'leap-frog' hypothesis, the distances to travel in early medieval Northern Europe were small in terms of sailing and rowing time - particularly in comparison with contemporary land transport (e.g. Carver 1990; Englert 2007). To provide just one example, the sea voyage from Norway to Ireland probably took less than two weeks based on medieval 
sources (e.g. Benediktsson 1968: 33, regarding the indirect route via Iceland). Early bases in the Northern Isles of Scotland were not an essential precondition for the Viking Age as we know it.

It remains for future studies to fully address the implications of the 'leap-frog' hypothesis for the migrant experience in the west. It would allow the possibility that Norse and Irish adventurers met in the Northern Isles or the Faeroes in the years leading up to the ninth century, a contact providing knowledge of the riches that lay in the Celtic monasteries (cf. Dumville 2002; Edwards 2005; Hannon et al. 2005). The theory may also alter the traditional model of Scandinavian immigration to Atlantic Scotland - which envisions a pioneer stage of contact, a consolidation stage of settlement and an establishment stage in which indigenous material culture was replaced in one way or another (e.g. Buteux 1997: 262; Morris 1998; Graham-Campbell 2003: 128-9). If the Irish Sea (a traditional centre of cultural influence for Atlantic Scotland) became a 'Norwegian lake' early in the Viking Age, perhaps Scandinavian material culture was adopted before settlement - reversing the traditional order.

In contrast with the western story, it could be argued that the eastern Scandinavian diaspora was a wave of advance, consistent with an underlying demographic imperative. It ultimately involved the sequential foundation of Staraja Ladoga, Novgorod and Kiev (Price 2000; Duczko 2004). Even in this case, however, one sees a 'leap-frog' between the Scandinavian kingdoms of the Baltic and the first trading settlement on Lake Ladoga in Russia (with its access to both furs and trade routes to the east). For example, Scandinavian influenced burials seem to have first appeared in intevening regions such as Estonia later in the Viking Age, during the tenth century (Mägi 1999: 35).

\section{The marriage imperative}

Thus far, I have minimised the relevance of settlement expansion and 'population pressure' to the origins of the Viking Age. It may be, however, that other aspects of demography merit further attention. Critical among these are the issues of gender and infanticide. It has long been established that much Viking Age loot of Insular origin (that is from Ireland or Britain) ultimately found its way into female Viking Age graves in western Norway (Wamers 1985; 1998; Graham-Campbell 2001; Raven 2005: 43). It has also been proposed that Iron Age female grave-goods in Scandinavia may well represent 'bride-wealth' in at least a general sense of the term (Arrhenius 1995; Kristoffersen 2004). Put together, one must ask: were the earliest Viking raids motivated to acquire such goods (cf. Burström 1993 regarding Gotlandic silver hoards)? Elsewhere in early medieval Europe young aristocratic men often served as warriors in the retinues of others - or alternatively formed military brotherhoods - until they married and established their own households (Brooks 1971: 74; Halsall 2003: 50, 106-8). Based on this analogy (and later medieval Norse sources) it is easy to imagine participation in raiding parties as part of a Scandinavian male's life cycle in the early Viking Age. On a comparative anthropological canvas perhaps plunder, like short-term urban labour, could provide the cash needed to succeed in the rural context - to accumulate bride-price, provide a dowry, or buy a home' (Brettell 2000: 102). 
This hypothesis merits further attention in the context of recent work on 'youth bulge' theory (Heinsohn 2003), which posits that warfare is often a corollary of societies in which young men represent a disproportionately large element of the population. In these cases there are simply not enough status roles to go around, leading to violent competition. Such a demographic imbalance could occur for many reasons, but selective female infanticide is an obvious candidate in the context of pre-Christian Scandinavia (Clover 1988: 169-70; Wicker 1998 and references therein). This interpretation differs from nebulous demographic determinism in that it depends on the internal structure of the population, rather than its size, and on the social practices which might have created it. Why might this issue have become critical in the late eighth century? One possibility is that increasingly militaristic competition associated with Scandinavian state formation (an issue to which I will return below) led to a preference for sons over daughters.

\section{Economic determinism}

Turning to urbanism and trade, arguments that emphasise their relevance to the Scandinavian diaspora are probably unassailable in very general terms. They do, however, merit reconsideration in detail. Western Europe's proto-urban centres, the so-called wics, boomed in the 'long eighth century' (Hansen \& Wickham 2000; Hill \& Cowie 2001) and became frequent targets of Viking raids by the 830s to 840s (Hill 1981: 33). Moreover, a trickle of silver from the Abbasid Caliphate first reached Scandinavian settlements in northwestern Russia and the Baltic in the last two decades of the eighth century - quickly turning into a flood. One of the earliest examples is a hoard of Oriental coins dating between 749 and 786 found near the Swedish influenced settlement of Staraja Ladoga (Duczko 2004: 67). Duczko (2004: 62) describes the resulting expansion of Scandinavian trade in the east as 'silver fever'. The ebb and flow of this wealth has been viewed as a major driver of events in Viking Age Europe since at least the writing of Henri Pirenne (Pirenne 1939: 239-40; Bolin 1953; Randsborg 1980: 152-62; Hodges \& Whitehouse: 1983: 111-22; McCormick 2001: 606-13; Woolf 2007: 54; cf. Hodges 2006). Nevertheless, within this intellectual tradition opinion differs as to whether it was the presence of Arabic silver, or periodic reductions in its availability, which fuelled Scandinavian raiding in the west.

Disentangling the threads of these arguments, it is possible to make two relevant observations. Assuming that news could travel quickly in early Viking Age Europe (as implied by the network analyses of Sindbæk 2007a \& b), it is entirely possible that the resulting gold rush mentality (Duczko's 'silver fever'), spread immediately to western Scandinavia. The earliest raids, often on monastic treasuries, in Britain, Ireland and (to a lesser degree) the Frankish empire could well have been the result. If so, however, one must imagine that the acquired wealth was for Scandinavian consumption - rather than transhipment to the Islamic world. Based on Arab sources, the Rus (Scandinavian traders) brought furs and swords to Baghdad in the ninth century (McCormick 2001: 610-11). Neither of these were major products of Britain or Ireland. Slaves first entered the record of Scandinavian exchange with the caliphate in the early tenth century. However, there were western markets for western slaves (Holm 1986) and eastern sources were available to meet eastern demand (McCormick 2001: 733-77). Early Viking Age Scandinavia was part of a world-system, but 
it would probably be an exaggeration to speculate that monks captured at Lindisfarne in AD 793 ended their days in Iraq.

Secondly, the beginning of Viking Age raiding in Western Europe was not focused on urban centres, nor even on urbanised regions. The earliest targets were mainly monasteries and other settlements in rural areas of northern England, Scotland and Ireland (Hill 1981: 33; Etchingham 1996). The actors in these raids were probably also of predominately rural background, if the traditional interpretation that they were mostly from western Norway remains valid (e.g. Wamers 1998). In short, the Viking Age began as a rural rather than an urban phenomenon. It may thus also have had little to do with targeting southern North Sea and western Baltic trade - which was most intensive in the shipping lanes between wics at sites such as York, Dorestad, Ribe, Hedeby and Birka based on the distribution of eighthto ninth-century coin and glass finds (e.g. Näsman 2000b). In the southern North Sea, for example, the earliest direct archaeological evidence for 'Viking' activity in the Carolingian empire is a silver hoard (Westerklief I) deposited around 850 in what is now the Netherlands (Besteman 2004). As noted above, moreover, historical sources indicate that raiding did not become common in this urbanised zone until the 830s to 840s (Keynes 1997; Nelson 1997)despite being routine in the rural north and west since 793. Early ninth-century records regarding the southern North Sea are mostly of successful defence against pirates, rather than the reverse (cf. Brooks 1971; Sawyer 1982b: 78-97). If western trade played a role in the earliest decades of the Viking Age, the mechanism must have been indirect.

\section{Political determinism}

Past arguments based on political determinism entail both external 'pull' and internal 'push' factors. Traditionally, weaknesses in the polities targeted by Scandinavian raiders have been interpreted as one of the most important political 'pull' factors. Like North Sea trade, however, this argument may merit rethinking. The problem is partly chronological. The episodes of political unrest which are known to have attracted Viking armies to one side or the other of the English Channel began decades into the ninth century (Brooks 1979; Wormald 1982). The earliest recorded Viking raids were paradoxically contemporary with the existence of strong hegemonic powers in both Anglo-Saxon England (Offa's Mercia) and continental Europe (Charlemagne's Frankish empire) (Hernæs 1997: 61). The lure of political meltdown is probably equally irrelevant to eighth- and ninth-century Scotland and Ireland, albeit for different reasons. Both regions were subdivided into many small competitive kingdoms - chiefdoms in comparative terminology (Earle 1997) - which must have had much in common with contemporary polities in Norway (cf. Myhre 1987: 186-7; O Cróinín 1995; Woolf 2007). It is hard to imagine that they offered a softer target than neighbouring communities at home.

Turning to 'push' factors, the observation that the Scandinavian diaspora began in a time of powerful neighbours leads directly to one of the longest-standing and most convincing ingredients in the Viking Age recipe. That is the centralisation of power within Scandinavian kingdoms and the diverse consequences of this process. Like 'wave of advance' assumptions, this idea owes its ultimate origin to medieval Scandinavian sources (which attribute Norse settlement in the west to the partly fictitious unification of Norway under Harald Fairhair) 
(e.g. Jónsson 1911: 53-4). However, it remains ubiquitous to the present day. In the words of Bjørn Myhre (2003: 60-1) (regarding the whole of the Scandinavian Iron Age, of which the Viking Age is the final subdivision):

The history of Scandinavia in the Iron Age is an example of changes of cultural and
political relations on the borders of an empire, from egalitarian tribal societies to
chiefdoms and petty kingdoms. This development was a consequence of influence and
pressure exerted from the major centres of continental Europe and of the positive actions
of local political players and entrepreneurs operating in relation both to more distant
centres and to their neighbouring societies.

The influence of powerful neighbours, particularly the Carolingian empire, took many forms. Firstly, they provided models to emulate in terms of both centralised power and the potential role of plunder in maintaining a military following (Reuter 1985). Secondly, they prompted an unambiguous need for defensive political centralisation. Thirdly, piracy was a viable option for contenders in the realpolitik of the resulting competition within and between elite Scandinavian dynasties. Lastly, the west provided havens and military training grounds for exiles - some of whom reverted from client game-keepers to free-booting poachers (Coupland 1998).

To understand these processes in concrete terms it is worth briefly considering the perpetrators of Viking raids (cf. Lund 1989: 47-56). Many remained nameless. Some, however, entered the historical record as recognised actors. There were leaders without royal associations, such as Saxolb who died in Ireland in 837 (Downham 2007: 268). There were royal deputies, such as Tomrair of Laithlinn who died with 1200 others in Ireland in 848 (Downham 2007: 274). There were exiled members of royal dynasties, such as Harald of Denmark who participated in Carolingian civil war in 841 (cf. Lund 1989: 47; Coupland 1998: 90-1). Lastly, if one accepts Godfrid of Denmark's Frisian campaign of 810 as 'Viking' activity (I would not), there were reigning kings themselves (Scholz 1970: 91-3).

All warriors in early medieval Europe were of elite status. To bear arms was to be a participant in politics (Halsall 2003). Within this broad social category, however, Viking raids would appear to have bolstered the treasuries of many different kinds of men. This applied to the relative status of leaders, but also to their crews. At one end of the scale, wealth could be acquired to marry and establish a household as already discussed (cf. Halsall 2003: 50-8, 106-8). At the other, wealth and its redistribution to a military retinue was the basis of chiefly and royal power (Reuter 1985). The role of raids probably escalated along this scale during the first five decades of the Viking Age (Ó Corráin 1998b: 425). Godfrid aside, the participation of royal deputies and dynasts noted above is first recorded in the 840 s. The evidence (such as it is) of fleet sizes tells the same story - rising from three at the end of the eighth century (Portland), to 13 in 820 (northern and western Frankia) to two fleets of 60 in 837 (Ireland) (Nelson 1997: 39; Hennessy 1998: 339).

Heightened competition within Scandinavia may also have led to the freeing of slaves to cultivate new land, creating a group of free men seeking 'an opportunity to win wealth and reputation' (Skre 2001: 12). Alternatively, it has been argued that the expansionistic military and ecclesiastical policies (including early missions into Scandinavia) of the Christian 
kingdoms of Western Europe may have inspired an ideologically driven reaction among the pagan elites of the north (Myhre 1993).

\section{Ideological determinism}

Many of the arguments summarised above regarding political centralisation are well established by contemporary archaeological and historical evidence. Others, such as Bjørn Myhre's 'pagan reaction' model, Dagfinn Skre's 'slavery hypothesis' and the 'gendered demography' theory proposed in this paper must remain more controversial (all having been offered in heuristic fashion). Their value lies in focusing attention on possible social factors behind the Viking Age Scandinavian diaspora. These are likely to be critical in a society where religion, mentality and warfare were inextricably linked (Price 2002).

Pursuing social causation further, two facets of Scandinavian ideology must have played an important role in the highly militarised and risky context of the Viking Age diaspora: honour and fatalism (e.g. Kuhn 1977: 162-3; Roesdahl 1991: 190; Simek 2004: 15). Without deeply seated beliefs in duty and predestination - and the iron hand of peerpressure - it is difficult to imagine how crews could have been recruited for journeys from which return was doubtful throughout the Viking Age. Risks were manifold and manifest from shipwreck and disease to violent death in battle. A wide range of primary sources (western, Arabic and Scandinavian) leave us in no doubt that many men did not survive their expeditions (e.g. Minorsky 1958: 152-3; Nelson 1991: 127; Sawyer 2000: 132). To grasp why people were willing to embark on these high-risk enterprises it is worth citing Price's (2002: 53) evaluation of religious belief in Viking Age Scandinavia:

We are left with a sobering conclusion, which is that the Vikings created one of the few known world mythologies to include the pre-ordained and permanent ruin of all creation and all the powers that shaped it, with no lasting afterlife for anyone at all. The cosmos began in the frozen emptiness of Ginnungagap, and will end in fire with the last battle. Everything will burn at the Ragnarok, whatever gods and humans may do. The outcome of our actions, our fate, is already decided and therefore does not matter. What is important is the manner of our conduct as we go to meet it. The psychological implications of this and other aspects of the Norse 'religion' bear thinking about.

Nevertheless, there is no reason to think that beliefs in honour and fate were unique to Scandinavia, or to the Viking Age. They probably characterised most of 'Barbarian' Europe for much of the first millennium AD and (in places) beyond (Halsall 2003). A mentality geared for war is thus only a precondition for the Viking Age diaspora - at least until convincing evidence for a dramatic change in Scandinavian world view can be established for the eighth century.

\section{Conclusions}

This brief survey of the causes of the Viking Age has sought to alter received wisdom in several ways. The Scandinavian diaspora was not a product of technological, climatic or economic determinism. Nor did it result from 'overpopulation' or the lure of weak neighbours. Instead, bands of 'surplus' young men (perhaps resulting from selective female infanticide) in need of 
bride-wealth may have set out in search of treasure. As has long been recognised, they were joined by would-be chieftains, royal deputies and exiles - seeking wealth to prevail in the face of increasing competition within Scandinavia. These motives combined with a fatalistic mentality to create what we observe as the beginning of the Viking Age. It may be unrealistic to pinpoint the spark that ignited this explosive cocktail. Nevertheless, one well-trodden option is the sudden availability of Abbasid coinage in the east - and western Scandinavia's efforts to find a comparable source of wealth. Another is a hypothetical meeting of Irish and Norse on the Faeroe Islands - opening a route to the monastic riches of the Irish Sea region. It is enough to say that to explore the causes of the Viking Age one must give equal emphasis to sweeping processes of the longue durée and rapid, contingent, developments. Three ship-crews at Portland between 786 and 802 could not have anticipated that most of Anglo-Saxon England would be conquered by Viking armies in the 870s (Brooks 1979). Nevertheless, they were part of the causal chain that led to this eventuality - and many others.

\section{Acknowledgements}

I thank Atholl Anderson, Ole Crumlin-Pedersen, Pieterjan Deckers, Clare Downham, Stephen Harrison, Catherine Hills, Sarah King, Neil Price, Martin Rundkvist, Peter Sawyer, Søren Sindbæk and Christer Westerdahl for helpful discussions and email correspondence while working on the text. The paper was also much improved by the comments of Martin Carver, James Graham-Campbell, Julian Richards and an anonymous referee. Liz Farmar kindly copy-edited the manuscript.

\section{References}

Andersen, S.T., B. Aaby, B. Odgaard \& E. Stenestad. 1988. Bæredygtigt landbrug. Danmarks Geologiske Undersøgelse Årsberetning 1988: 26-9.

Arneborg, J. 2003. Norse Greenland: reflections on settlement and depopulation, in J.H. Barrett (ed.) Contact, continuity and collapse: the Norse colonization of the North Atlantic (Studies in the Early Middle Ages 5): 163-82. Turnhout: Brepols.

Arrhenius, B. 1995. Women and gold: on the role of women in society at the time of the Great Migrations and their relationship to the production and distribution of ornaments, in H.G. Resi (ed.) Produksjon og samfunn: 85-96. Oslo: Universitetets Oldsaksamling.

Ashby, S.P. 2006. Time, trade and identity: bone and antler combs in early medieval northern Britain. Unpublished PhD dissertation, University of York.

Ballin Smith, B. 1995. Reindeer antler combs at Howe: contact between late Iron Age Orkney and Norway. Universitetets Oldsaksamling Årbok 1993/1994: 207-11.

- 2007. Norwick: Shetland's first Viking settlement?, in B.B. Smith, S. Taylor \& G. Williams (ed.) West over sea: studies in Scandinavian sea-borne expansion and settlement before 1300: 287-98. Leiden: Brill.
Barrett, J.H. 2003. Culture contact in Viking Age Scotland, in J.H. Barrett (ed.) Contact, continuity and collapse: the Norse colonization of the North Atlantic (Studies in the Early Middle Age 5): 73-111. Turnhout: Brepols.

- 2006. Migration and identity in Viking Age Scotland: interdisciplinary approaches. Unpublished paper presented at Migration in the First Millennium AD workshop, Oxford, 16-17 June 2006.

Barrett, J.H. \& M.P. Richards. 2004. Identity, gender, religion and economy: new isotope and radiocarbon evidence for marine resource intensification in early historic Orkney, Scotland. European Journal of Archaeology 7: 249-71.

Benediktsson, J. (ed.) 1968. Íslendingabók, Landnámabók. Reykjavík: Hið Îslenzka Fornritafélag.

Besteman, J. 2004. Two Viking hoards from the former island of Wieringen (The Netherlands): Viking relations with Frisia in an archaeological perspective, in J. Hines, A. Lane \& M. Redknap (ed.) Land, sea and home: proceedings of a conference on Viking-period settlement (Society for Medieval Archaeology Monograph 20): 93-108. Leeds: Maney.

Biddle, M. \& B. KJølbye-Biddle. 2001. Repton and the 'great heathen army', 873-4, in J. GrahamCampbell, R. Hall, J. Jesch \& D.N. Parsons (ed.) Vikings and the Danelaw: 45-96. Oxford: Oxbow. 
Bolin, S. 1953. Mohammed, Charlemagne and Ruric. Scandinavian History Review 1: 5-39.

Bradley, R.S., M.K. Hughes \& H.F. Diaz. 2003. Climate in medieval time. Science 302: 404-5.

Brettell, C.B. 2000. Theorizing migration in anthropology: the social construction of networks, identities, communities and globalscapes, in C.B. Brettell \& J.F. Hollifield (ed.) Migration theory: talking across disciplines: 97-136. London: Routledge.

Brink, S. \& N. Price (ed.). In press. The Viking world. London: Routledge.

Brooks, N. 1971. The development of military obligations in eighth- and ninth-century England, in P. Clemoes \& K. Hughes (ed.) England before the Conquest: 69-84. Cambridge: Cambridge University Press.

- 1979. England in the ninth century: the crucible of defeat. Transactions of the Royal Historical Society 29: 1-20.

Burström, M. 1993. Silver as a bridewealth: an interpretation of Viking Age silver hoards on Gotland, Sweden. Current Swedish Archaeology 1: 33-7.

Buteux, S. (ed.) 1997. Settlements at Skaill, Deerness, Orkney: excavations by Peter Gelling of the prehistoric, Pictish, Viking and later periods, 1963-1981 (British Archaeological Reports British Series 260). Oxford: Archaeopress.

Byock, J. 2001. Viking Age Iceland. London: Penguin.

Carver, M.O.H. 1990. Pre-Viking traffic in the North Sea, in S. Macgrail (ed.) Maritime Celts, Frisians and Saxons: 117-25. London: Council for British Archaeology.

- 1995. On - and off - the Edda, in O. Olsen, J. Skamby Madsen \& F. Riek (ed.) Ship-shape: essays for Ole Crumlin-Pedersen: 305-12. Roskilde: Viking Ship Museum.

Clover, C.J. 1988. The politics of scarcity: notes on the sex ratio in early Scandinavia. Scandinavian Studies 60: 147-88.

Coupland, S. 1998. From poachers to gamekeepers: Scandinavian warlords and Carolingian kings. Early Medieval Europe 7(1): 85-114.

Crumlin-Pedersen, O. (ed.) 1995. The ship as symbol in prehistoric and medieval Scandinavia. Copenhagen: National Museum of Denmark.

- 2007. Aspects of the origin of Atlantic and Baltic seafaring. Paper presented at the Global Origins and Development of Seafaring Conference, University of Cambridge, 19-21 September 2007.

Dahl-Jensen, D., K. Mosegaard, N. Gundestrup, G.D. Clow, S.J. Johnsen, A.W. Hansen \& N. Balling. 1998. Past temperatures directly from the Greenland ice sheet. Science 282: 268-71.
Dansgaard, W., S.J. Johnsen, N. Reeh, N. Gundestrup, H.B. Clausen \& C.U. Hammer. 1975. Climatic changes, Norsemen and modern man. Nature 155: 24-8.

Downham, C. 2007. Viking kings of Britain and Ireland: the dynasty of Ivarr to AD 1014. Edinburgh: Dunedin Academic Press.

Duczкo, W. 2004. Viking Rus: studies on the presence of Scandinavians in Eastern Europe. Leiden: Brill.

Dugmore, A.J., C. Keller \& T.H. McGovern. 2007. Norse Greenland settlement: reflections on climate change, trade, and the contrasting fates of human settlements in the North Atlantic islands. Arctic Anthropology 44: 12-36.

Dumville, D.N. 2002. The North Atlantic monastic thalassocracy: sailing to the desert in early medieval insular spirituality, in B.E. Crawford (ed.) The Papar in the North Atlantic: environment and history (St John's House Papers No. 10): 121-30. St Andrews: Committee for Dark Age Studies, University of St Andrews.

Dyer, C. 2002. Making a living in the Middle Ages. London: Yale University Press.

EArle, T. 1997. How chiefs come to power: the political economy in prehistory. Stanford: Stanford University Press.

Edwards, K.J. 2005. On the windy edge of nothing: a historical ecology of the Faroe Islands. Human Ecology 33: 585-96.

Ekrem, I. \& L. Boje Mortensen (ed.). 2003. Historia Norwegie. Copenhagen: Museum Tusculanum Press, University of Copenhagen.

EngLERT, A. 2007. Ohthere's voyages seen from a nautical angle, in J. Bately \& A. Englert (ed.) Ohthere's Voyages: a late 9th-century account of voyages along the coasts of Norway and Denmark and its cultural context: 117-29. Roskilde: Viking Ships Museum.

Etchingham, C. 1996. Viking raids on Irish Church settlements in the ninth century. Maynooth: St Patrick's College Maynooth.

- 2007. The location of historical Laithlinn/ Lochla(i)nn: Scotland or Scandinavia?, in M. O Flaithearta (ed.) Proceedings of the seventh symposium of Societas Celtologica Nordica (Acta Universitatis Upsaliensis 6): 11-31. Uppsala: Uppsala University.

Forenbaher, S. \& P.T. Miracle. 2005. The spread of farming in the Eastern Adriatic. Antiquity 79: 514-28.

Fossier, R. 1999. Rural economy and country life, in T. Reuter (ed.) The new Cambridge Medieval History: volume III c. 900 - c. 1024: 27-63. Cambridge: Cambridge University Press. 
Graham-CampBell, J.A. 1975. Bossed penannular brooches: a review of recent research. Medieval Archaeology 19: 33-47.

- 1995. The Viking-Age gold and silver of Scotland. Edinburgh: National Museums of Scotland.

- 1998. The Early Viking Age in the Irish Sea area, in H. Clarke, M. Ní Mhaonaigh \& R. Ó Floinn (ed.) Ireland and Scandinavia in the Early Viking Age: 104-30. Dublin: Four Courts.

- 2001. National and regional identities: the 'glittering prizes', in M. Redknap, N. Edwards, S. Youngs, A. Lane \& J. Knight (ed.) Pattern and purpose in Insular art: 27-38. Oxford: Oxbow.

- 2003. The Vikings in Orkney, in D.J. Waugh (ed.) The faces of Orkney: stones, skalds and saints: 128-37. Edinburgh: Scottish Society for Northern Studies.

GuĐmundsson, F. (ed.) 1965. Orkneyinga Saga. Reykjavík: Hið Islenzka Fornritafélag.

Hadley, D.M. 2006. The Vikings in England: settlement, society and culture. Manchester: Manchester University Press.

Halsall, G. 2003. Warfare and society in the Barbarian West 450-900. London: Routledge.

Hannon, G.E., R.H.W. Bradshaw, E.G. Bradshaw, I. SNowball \& S. WastegArd. 2005. Climate change and human settlement as drivers of late-Holocene vegetational change in the Faroe Islands. The Holocene 15: 639-47.

Hansen, I.L. \& C. Wickham (ed.). 2000. The long eighth century: production, distribution and demand. Leiden: Brill.

Haywood, J. 1999. Dark Age naval power: a reassessment of Frankish and Anglo-Saxon seafaring activity. Hockwold-cum-Wilton: Anglo-Saxon Books.

Hedeager, L. 1992. Iron-Age societies: from tribe to state in Northern Europe 500 BC to AD 700. Oxford: Blackwell.

Heinsohn, G. 2003. Söhne und Weltmacht: Terror im Aufstieg und Fall der Nationen. Zürich: Orell Füssli.

Hennessy, W.M. (ed.) 1998. Annals of Ulster volume I. Dublin: Éamonn de Búrca.

Hernæs, P. 1997. Storpolitikk og vikingtog på slutten av 700-tallet, in I. Fuglestvedt \& B. Myhre (ed.) Konflikt i forhistorien (AmS Varia 30): 57-67. Stavanger: Arkeologisk Museum i Stavanger.

Hill, D. 1981. An atlas of Anglo-Saxon England. Toronto: University of Toronto Press.

Hill, D. \& R. Cowie. 2001. Wics: the early medieval trading centres of Northern Europe. Sheffield: Sheffield Academic Press.

Hills, C. 2003. The origins of the English. London: Duckworth.

Hodges, R. 2006. Goodbye to the Vikings? in R. Hodges (ed.) Goodbye to the Vikings? Re-reading early medieval archaeology: 157-62. London: Duckworth.
Hodges, R. \& D. Whitehouse. 1983. Mohammed, Charlemagne \& the origins of Europe: archaeology and the Pirenne thesis. London: Duckworth.

Holm, P. 1986. The slave trade of Dublin, ninth to twelfth centuries. Peritia 5: 317-45.

Hughes, M.K. \& H.F. Diaz. 1994. Was there a 'Medieval Warm Period', and if so, where and when. Climatic Change 26: 109-42.

Hunter, J. 2007. The interface and Scandinavian settlement, in J. Hunter, J.M. Bond \& A.N. Smith (ed.) Investigations in Sanday, Orkney. Volume 1: excavations at Pool, Sanday. Multi-period settlement from Neolithic to Late Norse times: 121-45. Kirkwall: The Orcadian/Historic Scotland.

Johnson, R. 2001. The development of Irish brooch forms and pins in the Viking Age, c. 850-1170. Peritia 15: 321-62.

Jónsson, F. (ed.) 1911. Snorri Sturluson: Heimskringla. København: G.E.C. Gads.

Karlsson, S. \& A.-M. Robertsson. 1997. Human impact in the Lake Mälaren region, south-central Sweden during the Viking Age (AD 750-1050): a survey of biostratigraphical evidence, in U. Miller \& H. Clarke (ed.) Environment and Vikings: scientific methods and techniques: 47-72. Stockholm: Birka Project.

KeEgan, W.F. 2004. Islands of Chaos, in A. Delpuech \& C.L. Hofman (ed.) Late ceramic age societies in the eastern Caribbean (British Archaeological Reports International Series 1273): 33-44. Oxford: Archaeopress.

Keynes, S. 1997. The Vikings in England, c. 790-1016, in P. Sawyer (ed.) The Oxford illustrated history of the Vikings: 48-82. Oxford: Oxford University Press.

Kristoffersen, S. 2004. Bridal jewels - in life and death, in T. Oestigaard, N. Anfinset \& T. Saetersdal (ed.) Combining the past and the present: archaeological perspectives on society (British Archaeological Reports International Series 1210): 31-7. Oxford: Archaeopress.

Kunn, H. 1977. Uns ist Fahrwind gegeben wider den Tod: aus einer großen Zeit des Nordens. Zeitschrift für Deutsches Altertum und Deutsche Literatur 106: 147-63.

Lund, N. 1989. Allies of God or man? The Viking expansion in a European perspective. Viator 20: 45-59.

MäGI, M. 1999. Viking Age inhumations in Estonia new interpretations, in P. Purhonen (ed.) Fenno-Ugria et Slavi 1997: cultural contacts in the area of the Gulf of Finland in the 9th-13th centuries: 29-43. Helsinki: Museovirasto.

McCormick, M. 2001. Origins of the European economy: communication and commerce $A D$ 300-900. Cambridge: Cambridge University Press. 
Michelli, P. 1993. Migrating ideas or migrating craftsmen? The case of the bossed penannular brooches, in R.M. Spearman \& J. Higgitt (ed.) The Age of migrating ideas: early medieval art in northern Britain and Ireland: 182-7. Edinburgh: National Museums of Scotland \& Stroud: Sutton.

Minorsky, V. 1958. Mas'ūdi on the Caucasus, in V. Minorsky (ed.) A history of Sharvān and Darband in the 10th-11th centuries. Cambridge: W. Heffer \& Sons.

Montgomery, J. \& J.A. Evans. 2006. Immigrants on the Isle of Lewis: combining traditional funerary and modern isotope evidence to investigate social differentiation, migration and dietary change in the Outer Hebrides of Scotland, in R. Gowland \& C. Knusel (ed.) The social archaeology of funerary remains: 122-42. Oxford: Oxbow.

Montgomery, J., J.A. Evans \& T. Neighbour. 2003. $\mathrm{Sr}$ isotope evidence for population movement within the Hebridean Norse community of NW Scotland. Journal of the Geological Society 160: 649-53.

Morris, C.D. 1998. Raiders, traders and settlers: the Early Viking Age in Scotland, in H. Clarke, M. Ní Mhaonaigh \& R. Ó Floinn (ed.) Ireland and Scandinavia in the Early Viking Age: 73-103. Dublin: Four Courts Press.

Müller-Wille, M. 1994. Der politische Mißbrauch der Skandinavischen Vor- und Frühgeschichte während der Jahre 1933-1945. Offa 51: 25-35.

Myrre, B. 1987. Chieftains' graves and chiefdom territories. Studien zur Sachsenforschung 7: 169-87.

- 1993. The beginning of the Viking Age - some current archaeological problems, in A. Faulkes \& R. Perkins (ed.) Viking revaluations: 182-204. London: Viking Society for Northern Research, University College London.

- 1998. The archaeology of the early Viking Age in Norway, in H. Clarke, M. Ní Mhaonaigh \& R. O Floinn (ed.) Ireland and Scandinavia in the Early Viking Age: 3-36. Dublin: Four Courts.

- 2003. The Iron Age, in K. Helle (ed.) The Cambridge History of Scandinavia: 60-93. Cambridge: Cambridge University Press.

Näsman, U. 1991. Sea trade during the Scandinavian Iron Age: its character, commodities and routes, in O. Crumlin-Pedersen (ed.) Aspects of maritime Scandinavia AD 200-1200: 23-40. Roskilde: Viking Ship Museum.

- 2000a. Raids, migrations and kingdoms - the Danish case. Acta Archaeologica 71: 1-7.

- 2000b. Exchange and politics: the eighth-early ninth century in Denmark, in I.L. Hansen \& C. Wickham (ed.) The long eighth century: production, distribution and demand: 35-68. Leiden: Brill.
Nelson, J.L. (ed.) 1991. The Annals of St-Bertin. Manchester: Manchester University Press.

- 1997. The Frankish empire, in P. Sawyer (ed.) The Oxford Illustrated History of the Vikings: 19-47. Oxford: Oxford University Press.

Nondier, G. 2002. Le mythe viking en Normandie et ses paradoxes, in E. Ridel \& P. Bouet (ed.) L'héritage maritime des Vikings en Europe de l'Ouest: 503-12. Caen: Presses Universitaires de Caen.

Ó Corráin, D. 1998a. The Vikings in Scotland and Ireland in the ninth century. Peritia 12: 296-339.

- 1998b. Viking Ireland - afterthoughts, in H. Clarke, M. Ní Mhaonaigh \& R. O Floinn (ed.) Ireland and Scandinavia in the Early Viking Age: 421-52. Dublin: Four Courts.

O CRóinín, D. 1995. Early medieval Ireland, 400-1200. London: Longman.

Oppenheimer, S. 2007. The origins of the British: a genetic detective story. London: Robinson.

Owen, O. \& M. Dalland. 1999. Scar: a Viking boat burial on Sanday, Orkney. East Linton: Tuckwell Press.

Paterson, C. 2001. Insular belt-fittings from the pagan Norse graves of Scotland: a reappraisal in the light of scientific and stylistic analysis, in M. Redknap, N. Edwards, S. Youngs, A. Lane \& J. Knight (ed.) Pattern and purpose in Insular art: 125-32. Oxford: Oxbow.

Pirenne, H. 1939. Mohammed and Charlemagne. London: Allen \& Unwin.

Price, N. 2000. Novgorod, Kiev and their satellites: the city-state model and the Viking Age polities of European Russia, in M.H. Hansen (ed.) $A$ comparative study of thirty city-state cultures: 263-75. Copenhagen: Royal Danish Academy of Sciences and Letters.

- 2002. The Viking way: religion and war in late Iron Age Scandinavia (AUN 31).Uppsala: Department of Archaeology and Ancient History, University of Uppsala.

Randsborg, K. 1980. The Viking Age in Denmark: the formation of a state. London: Duckworth.

- 1995. Hjortspring: warfare and sacrifice in early Europe. Aarhus: Aarhus University Press.

- 2000. Colonization: Greek and Viking. Acta Archaeologica 71: 171-82.

Raven, S. 2005. The Scandinavian bowls, in R.L.S. Bruce-Mitford (ed.) A corpus of Late Celtic hanging-bowls: 41-61. Oxford: Oxford University Press.

Reuter, T. 1985. Plunder and tribute in the Carolingian Empire. Transactions of the Royal Historical Society 35: 75-94.

Richards, J.D. 2000. Viking Age England. Stroud: Tempus. 
Ridel, E. 2007. From Scotland to Normandy: the Celtic sea route of the Vikings, in B.B. Smith, S. Taylor \& G. Williams (ed.) West over sea: studies in Scandinavian sea-borne expansion and settlement before 1300: 81-94. Leiden: Brill.

Roesdahl, E. 1991. The Vikings. Harmondsworth: Penguin.

SAntiago-Irizarry, V. 2008. Transnationalism and migration: locating sociocultural practices among Mexican immigrants in the United States. Reviews in Anthropology 37: 16-40.

SAwYer, B. 2000. The Viking-Age rune stones. Oxford: Oxford University Press.

SAwyer, P. 1982a. The causes of the Viking Age, in R.T. Farrell (ed.) The Vikings: 1-7. London: Phillimore.

- 1982b. Kings and Vikings: Scandinavia and Europe AD 700-1100. London: Methuen.

- 2003a. The Viking expansion, in K. Helle (ed.) The Cambridge History of Scandinavia: 105-20. Cambridge: Cambridge University Press.

- 2003b. Scotland, Ireland and Iceland: Norwegian settlers in the ninth century, in S. Lewis-Simpson (ed.) Vinland revisited: the Norse world at the turn of the first millennium: 29-36. St John's: Historic Sites Association of Newfoundland and Labrador.

Scholz, B.W. (ed.) 1970. Carolingian chronicles. Ann Arbor: University of Michigan Press.

Sheehan, J. 1998. Early Viking Age silver hoards from Ireland and their Scandinavian elements, in $\mathrm{H}$. Clarke, M. Ní Mhaonaigh \& R. Ó Floinn (ed.) Ireland and Scandinavia in the Early Viking Age: 166-202. Dublin: Four Courts.

SimeK, R. 2004. The emergence of the Viking Age: reasons and triggers, in R. Simek \& U. Engel (ed.) Vikings on the Rhine: recent research on early medieval relations between the Rhinelands and Scandinavia: 9-21. Wien: Fassbaender.

SINDBÆK, S.M. 2007a. Networks and nodal points: the emergence of towns in early Viking Age Scandinavia. Antiquity 81: 119-32.

$-2007 \mathrm{~b}$. The small world of the Vikings: networks in early medieval communication and exchange. Norwegian Archaeological Review 40: 59-74.

Skre, D. 2001. The social context of settlement in Norway in the first millennium AD. Norwegian Archaeological Review 34: 1-34.

Small, A., C. Thomas \& D.M. Wilson. 1973. St Ninian's Isle and its treasure. Oxford: Oxford University Press.
Stefánsson, M. 2003. The Norse island communities of the Western Ocean, in K. Helle (ed.) The Cambridge History of Scandinavia: 202-20. Cambridge: Cambridge University Press.

Svanberg, F. 2003. Decolonizing the Viking Age 1. Stockholm: Almqvist \& Wiksell International.

Vésteinsson, O., H. porlaksson \& A. Einarsson. 2006. Reykjavik 871+2 Landnamssýningin: the settlement exhibition. Reykjavík: Reykjavík City Museum.

Wallace, B.L. 2003. L'Anse aux Meadows and Vinland: an abandoned experiment, in J.H. Barrett (ed.) Contact, continuity and collapse: the Norse colonization of the North Atlantic (Studies in the Early Middle Ages 5): 207-38. Turnhout: Brepols.

WAMERs, E. 1985. Insularer Metallschmuck in wikingerzeitlichen Gräbern Nordeuropas: Unteruchungen zur Skandinavishen Westexpansion (Offa-Bücher 56). Neumünster: Wachholtz.

- 1998. Insular finds in Viking Age Scandinavia and the state formation of Norway, in H. Clarke, M. Ní Mhaonaigh \& R. Ó Floinn (ed.) Ireland and Scandinavia in the Early Viking Age: 37-72. Dublin: Four Courts.

WARNER, R. 1976. Scottish silver arm-rings: an analysis of weights. Proceedings of the Society of Antiquaries of Scotland 107: 136-43.

Weber, B. 1992. Norwegian exports in Orkney and Shetland during the Viking and Middle Ages, in R.A. Hall, R. Hodges \& H. Clarke (ed.) Medieval Europe 1992: exchange and trade pre-printed papers: 159-67. York: Medieval York 1992.

- 1993. Norwegian reindeer antler export to Orkney. Universitetets Oldsaksamling Årbok 1991/1992: 161-74.

Westerdahl, C. 2008. Boats apart: building and equipping an Iron-Age and early-medieval ship in Northern Europe. The International Journal of Nautical Archaeology 37: 17-31.

Wicker, N.L. 1998. Selective female infanticide as partial explanation for the dearth of women in Viking Age Scandinavia, in G. Halsall (ed.) Violence and society in the Early Medieval West: 205-21. Woodbridge: Boydell \& Brewer.

Wicкнам, C. 2005. Framing the Early Middle Ages: Europe and the Mediterranean, 400-800. Oxford: Oxford University Press.

Woolf, A. 2007. From Pictland to Alba: 789-1070. Edinburgh: Edinburgh University Press.

Wormald, C.P. 1982. Viking studies: whence and whither?, in R.T. Farrell (ed.) The Vikings: 128-53. London: Phillimore. 